\title{
Helsehjelp ved mobbing på arbeidsplassen
}

\author{
Nyere forskning tyder på sterke sammenhenger mellom mobbing på arbeidsplassen og psykiske og fysiske \\ helseplager. Forekomsten av mobbing i norsk arbeidsliv er godt dokumentert, men vi vet lite om hvilken behand- \\ ling som hjelper og sikrer videre yrkesdeltakelse for dem som har fått dårlig helse på grunn av mobbing. Jobb- \\ fast er det første utrednings- og behandlingstilbudet i Norge som spesifikt er rettet mot denne pasientgruppen.
}

Det er etter hvert godt dokumentert at konflikter, mobbing, seksuell trakassering og varsling $\mathrm{i}$ arbeidslivet er assosiert med redusert helse hos arbeidstakere (1). Langtidsstudier på effekter av mobbing viser økt forekomst av både psykiske og fysiske helseplager (2). I tillegg til de omkostninger dette har for den enkelte som rammes, regner man med betydelige samfunnsmessige kostnader. I Tyskland er det anslått at sykefravær på grunn av mobbing årlig koster virksomheter 2,3 milliarder euro (3).

I første del av 1990-årene ble 8-9\% av norske arbeidstakere mobbet (4). Dette var redusert til omkring det halve ved siste kartlegging i 2010 (5). Lovreguleringer, offentlig oppmerksomhet, økt kunnskap om fenomenet og landsdekkende kampanjer samt styrket forebyggende innsats har nok vært viktige faktorer for endringene. Forebyggende arbeid ser således ut til å ha hatt en effekt, men fortsatt opplever altså 4-5\% av norske yrkesaktive denne typen belastning på arbeidet.

På tross av omfattende oppmerksomhet omkring mobbing i Norge har de som har fått helseplager knyttet til dette ikke hatt noe spesialtilpasset tilbud om behandling og rehabilitering. Det er derfor begrenset klinisk erfaring med denne gruppen og således et stort behov for forskning på dette feltet.

\section{Jobbfast \\ Jobbfast er en forskningspoliklinikk for traumer og psykososiale belastninger i arbeidslivet. Den ble startet høsten 2011. Tilbudet inngår i den polikliniske virksom- heten ved Yrkesmedisinsk avdeling ved Haukeland universitetssykehus. Poliklinik- ken mottar pasienter fra hele landet, henvist fra lege eller psykolog i første- og annen- linjetjenesten. De som kan henvises, er per- soner med helseplager relatert til konflikter, mobbing, varsling og seksuell trakassering på arbeidsplassen. Pasienten trenger ikke være sykmeldt, men det er et krav at hen- viseren følger opp pasienten i etterkant av tilbudet ved Jobbfast.}

Pasienten går i løpet av tre dager gjennom et program med utredning, behandling og rehabilitering. Dette besørges av et team bestående av leger, psykolog, fysioterapeut og arbeidskonsulent. Det legges vekt på at pasienten får fortelle sin historie, og det gjøres en kartlegging av psykisk helse, en psykomotorisk fysioterapivurdering og en tradisjonell arbeidsmedisinsk utredning.
Videre blir det gitt en grundig pedagogisk gjennomgang med vekt dels på den aktuelle belastningen i arbeidsmiljøet som er bakgrunn for henvisningen, dels på generelle temaer omkring mobbing og konflikter.

Gjennomgangen bærer preg av at det etableres dialog med pasienten - de ulike temaene tas opp i samtaleform heller enn som tradisjonell undervisning. Den tredje dagen oppsummerer vi funn og vurderinger sammen med pasienten og drøfter videre tiltak, herunder slike som arbeidskonsu-

\section{«Det etableres dialog med pasienten - de ulike temaene tas opp i samtaleform heller enn som tradisjonell undervisning»}

lenten foreslår med tanke på tilrettelegging av jobbsituasjonen. Saken drøftes også med organisasjonspsykolog. I et telefonmøte med pasient og henvisende lege/psykolog fire uker senere gjennomgås hovedpunkter fra utredningen/programmet med vekt på veien videre.

I planleggingsfasen av Jobbfast har det vært et nært samarbeid med representanter for partene i arbeidslivet, brukerrepresentanter, ulike bedriftshelsetjenester og forskningsmiljøer ved Universitetet i Bergen, Bergen kommune og Divisjon psykisk helsevern ved Haukeland universitetssykehus. Forskningsgruppe for arbeidsmiljø, ledelse og konflikt ved Universitetet i Bergen har mange års erfaring innen mobbe- og arbeidsmiljøforskning $(1,4,6,7)$ og deltar med organisasjonspsykologisk kompetanse i utredningen. Med omfattende forskningserfaring og et stort internasjonalt nettverk har det vært en styrke at tilbudet kunne utvikles i nært samarbeid med denne forskningsgruppen.

\section{Forskning}

Forskning knyttet til poliklinikken skal gi kunnskap om hva som kjennetegner pasientene som utredes, hvilke faktiske helseplager de har samt hvilken behandling som gir bedre helse og fremmer tilbakeføring til jobb etter sykmelding. Under utredningen gjør vi en klinisk evaluering av pasientenes mentale helse og en psykomotorisk kartlegging (8). Klinisk intervju med diagnostisk strukturert intervju samt etablerte spørreskjemaer benyttes for å kartlegge tilstander som angst og depresjon. Pasientene følges opp med spørreskjemaene over tid.

For yrkesdeltakelse vil sykmeldingsdata og andre data fra Forløpsdatabasen Trygd (FD-trygd) bli benyttet. Dataene våre vil bli sammenholdt med data fra andre pasientgrupper og befolkningsdata.

Vi vet allerede at det samlede tap av yrkesdeltakelse blant våre pasienter er stort. Det er flere som har fått arbeidsavklaringspenger i tre år eller mer forut for henvisning til Jobbfast.

\section{Tilbakemeldinger og veien videre}

Erfaringen etter snart to års drift er at tilbudet oppleves som nyttig både for pasienter og henvisende fagpersonell. Pasienter har i muntlige og skriftlige tilbakemeldinger gitt uttrykk for at et slikt sammensatt tilbud er hensiktsmessig, men intenst. Vi har fått positive kommentarer fra henvisere på møteformen. Utredningen vurderes som praktisk nyttig. Effekten av tilbudet på den enkeltes helse og yrkesdeltakelse vet vi foreløpig lite om - forskningen må komme lenger før vi kan si noe om det.

Vi planlegger å tilby individuell behandling og gruppebehandling med undervisning og rehabilitering som et supplement for noen av pasientene. Tilbudet vil bli evaluert i studier med kontrollgrupper.

Hvorvidt det på sikt kan bli aktuelt å etablere et tilsvarende tilbud $i$ andre helseregioner, vil fremtiden vise. Nærmere informasjon om Jobbfast finnes på www.jobbfast.no.

\section{Kristin Buhaug \\ kristin.buhaug@helse-bergen.no \\ Tor Brøvig Aasen \\ Ståle Einarsen \\ Nils Magerøy}

Kristin Buhaug (f. 1965) er spesialist i arbeidsmedisin og overlege ved Yrkesmedisinsk avdeling. Haukeland universitetssykehus. Hun inngår i utredningsteamet for pasienter ved Jobbfast. Forfatter har fylt ut ICMJE-skjemaet og oppgir ingen interessekonflikter. 
Tor Brøvig Aasen (f. 1946) er spesialist i lungesykdommer og i indremedisin, med spesiell kompetanse innen arbeidsrelaterte lungesykdommer. Han er avdelingsoverlege og avdelingsdirektør ved Yrkesmedisinsk avdeling, Haukeland universitetssykehus.

Forfatter har fylt ut ICMJE-skjemaet og oppgir ingen interessekonflikter.

Ståle Einarsen (f. 1963) er dr.psychol., professor ved Institutt for samfunnspsykologi ved Universitetet i Bergen og leder av Forskningsgruppe for arbeidsmiljø, ledelse og konflikt (FALK).

Forfatter har fylt ut ICMJE-skjemaet og oppgir følgende interessekonflikter: Han driver et firma som gir opplæring i hvordan mobbesaker best skal håndteres internt i virksomheten.

Nils Magerøy (f. 1954) er lege, tidligere spesialist i allmennmedisin og har en ph.d. i arbeidsmedisin. Han er enhetsleder ved Jobbfast,

Yrkesmedisinsk avdeling, Haukeland universitetssykehus.

Forfatter har fylt ut ICMJE-skjemaet og oppgir ingen interessekonflikter.

\section{Litteratur}

1. Nielsen MB, Einarsen S. Outcomes of exposure to workplace bullying: a meta-analytic review. Work Stress 2012; 26: 309-32.

2. Einarsen S, Glasø L, Nielsen MB. Mobbing $i$ arbeidslivet: en litteraturoversikt. Tidsskrift for Norsk psykologforening 2008; 45: 308-17.

3. Von Dahlkamp S, Gezer Ö, Kaiser S et al. Kollege Feind. Der Spiegel 16.4.2012. www.spiegel.de/ spiegel/print/d-85065931.html (30.9.2013)

4. Nielsen MB, Skogstad A, Matthiesen SB et al. Prevalence of workplace bullying in Norway: comparisons across time and estimation methods. Eur J Work Organ Psychol 2009; 18: 81-101.

5. Arbeidsmiljøet i Norge og EU - en sammenligning basert på data fra European working conditions survey. Tab 6.12, kap. 6. STAMI-rapport nr. 7/2012. Oslo: Statens arbeidsmiljøinstitutt, 2012.

6. Einarsen S, Skogstad A. Bullying at work: epidemiological findings in public and private organizations. Eur J Work Organ Psychol 1996; 5: 185-201.

7. Einarsen S, Hoel H, Zapf D et al, red. Bullying and harassment in the workplace - developments in theory, research, and practice. Boca Raton, FL: CRC Press, 2011.

8. Kvåle A, Ljunggren AE, Johnsen TB. Examination of movement in patients with long-lasting musculoskeletal pain: reliability and validity. Physiother Res Int 2003; 8: 36-52.

Mottatt 5.9. 2013, første revisjon innsendt 20.9. 2013, godkjent 30.9. 2013. Redaktør Hanne Støre Valeur.

Engelsk oversettelse på www.tidsskriftet.no

Publisert først på nett. 